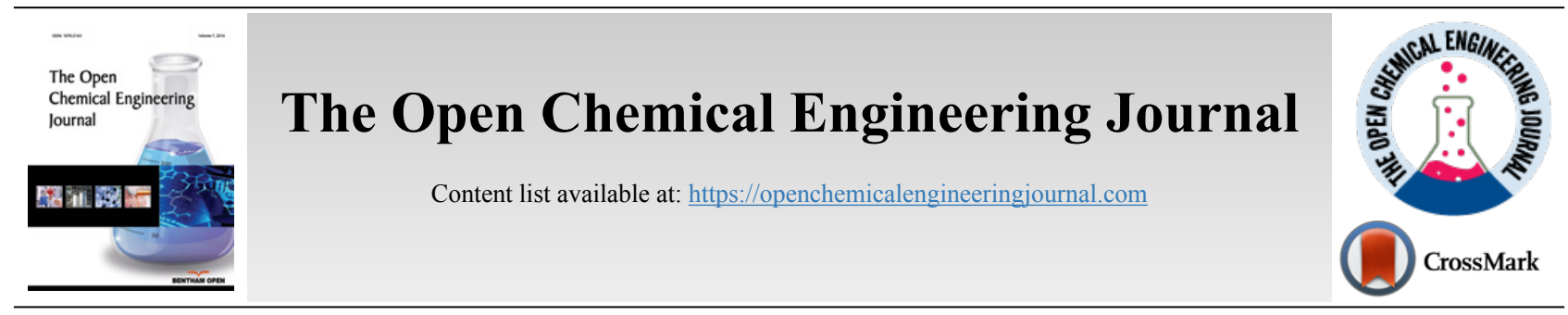

RESEARCH ARTICLE

\title{
Effect of Varying Drying Temperature on the Soluble Sugar and Nutritional Content of Banana
}

\author{
E.E Alagbe ${ }^{1, *(D)}$, Y.S Amlabu ${ }^{1}$, E.O Daniel ${ }^{2}$ and M.E Ojewumi ${ }^{1}$ \\ ${ }^{1}$ Department of Chemical Engineering, Covenant University, Ota, Nigeria \\ ${ }^{2}$ Department of Microbiology, Benson Idahosa University, Benin City, Nigeria
}

\begin{abstract}
:
Aims:

In this work, the effect of drying temperature on the available carbohydrate is investigated.

Background:

Nigerian climate favours the cultivation of banana and it is a ready fruit delight available in almost all homes. Hybrids and polyploids of the species musa acuminata and musa balbisiana are very common. Unfortunately, post-harvest losses of $40-60 \%$, of this energy rich fruit are encountered yearly. Drying is very old method of preservation which has stood the test of time. Bananas are known to possess high carbohydrates with low glycaemic index which makes it a healthy fruit or snack.

Objective:

To determine the optimum drying temperature for the drying of Banana fruit.

Methods:

The banana fruit was peeled and sliced to about $5 \mathrm{~mm}$ thickness and dried in a tray dryer at varying temperatures of $40{ }^{\circ} \mathrm{C}, 50{ }^{\circ} \mathrm{C}, 60{ }^{\circ} \mathrm{C}$ and $70{ }^{\circ} \mathrm{C}$. The control sample was air dried at the average prevailing temperature of $30^{\circ} \mathrm{C}$.

Results:

Results obtained showed that increased drying temperature leads to more loss of moisture from the samples and in turn, favoured an increase in the available carbohydrate in the dried fruit. The ash, fat and crude fibre content marginally changed with drying temperature.

Conclusion:

The optimum temperature for treated and untreated samples, from the results obtained, were $60{ }^{\circ} \mathrm{C}$ and $70{ }^{\circ} \mathrm{C}$ respectively.

Drying impacts positively on the available sugar in the Banana fruit.
\end{abstract}

Keywords: Available carbohydrate, Banana drying, Glycaemic index, Post-harvest loss, Proximate analysis, Cassava.

\begin{tabular}{|l|l|l|l|}
\hline Article History & Received: November 07, 2019 & Revised: January 24, 2020 & Accepted: January 29, 2020
\end{tabular}

\section{INTRODUCTION}

In Nigeria, ripe bananas are mostly eaten raw and in rare cases, made into flour. Dried fruits as snacks and toppings in cereals, pancakes, oat meals, etc are gradually being introduced and embraced in the community. Banana is one of the organic

\footnotetext{
* Address correspondence to this author at the Department of Chemical Engineering, Covenant University, Ota, Nigeria Tel: +2348123187054;

E-mail: edith.alagbe@covenantuniversity.edu.ng
}

products, most valued by buyers around the globe, basically because of its attributes. It has high nutritional value, is rich in starches and minerals, with a medium amount of sugar and vitamin A, but contains very little amount of protein [1]. Being an organic product, banana is prone to microbial conservative effect; especially during collection, post-gathering and utilization [2 - 5].

Most banana species found in Nigeria, have a very short shelf life of about 7 days. The moisture content of about $66 \%$ 
along with the storage temperature, ranging between $28^{\circ} \mathrm{C}$ and $35^{\circ} \mathrm{C}$, is a favourable combination for obtaining good quality fruit [6]. Microbial attacks are not an uncommon for banana due to its moisture and sugar content.

Dehydration or drying is a basic technique, which helps a lot to contain its nourishment that may some way [7] deteriorate. Drying of fruits reduces the weight of the fruit leading to reduced transport cost, longer shelf life and better availability all year round. Drying is an old technology for preserving fruits and vegetables and must be controlled painstakingly such that the quality traits of the dried natural products are retained and maintained [8]. This would permit to upgrade or change drying parameters continuously amid the drying procedure to guarantee great quality dried items [9]. Simple drying techniques which have stood the test of time are the open-air drying, which has the down-side of being contaminated with the atmosphere and also, there is the risk of being eaten by rodents and other animals. A lot of work has been done on the drying kinetics and characterization of the dried products using different tools.

Tray drying refers to drying out small quantity of the product by subjecting it to hot dry air or to the sun until it is dried enough to be stored at ambient temperature with almost negligible decay of the product [10]. Since dried bananas have various uses such as baby food, cereal, banana chips, banana bread, banana pudding and so many other delicious delicacies, it is imperative to choose a suitable method of drying for this specific product to maintain the nutrient levels in the fruit when dried.

Large varieties of banana exist ranging from green to the yellow species and recently, the red species have begun to gain attention - which are all hybrids and polyploids of the species, Musa acuminata and Musa balbisiana. Banana fruits majorly contain carbohydrates (presented as starch in unripe fruits but sugars in ripe fruits), fibre, antioxidants and vitamins. Its low glycaemic index (GI) makes its consumption attractive due to the absence of fear of increased blood sugar levels. The starch in an unripe banana debases to a few monosaccharides, while the remainder of the starch is degenerated to sucrose [11]. Being low on the glycaemic index, bananas release their energy into the bloodstream immediately [12]. The glycaemic index of bananas rises as the fruit matures [12, 13], which is advantageous for diabetic patients [14].

The banana fruit is also rich in potassium, magnesium and copper [15]. Potassium can be found in different fruits, vegetables and even meats, but a single banana supplies about $23 \%$ of potassium needed on a daily basis by an adult [14]. Potassium is a vital element of cell and body fluids, it aids muscles and nerves. It also controls heartbeat and blood pressure and counters the effect of sodium [15].

Almost all parts of the banana are used in different aspects [13]. The fruit, just like cassava, may vary in composition according to the variety [16]. The banana fruit can be eaten raw or cooked, processed into flour and can be fermented to produce beverages such as banana juice, beer, vinegar or wine $[13,17]$. In traditional medicine, the sap of the banana plant is used to treat a wide variety of ailments, including leprosy, hysteria, fever, digestive disorders, haemorrhage, epilepsy and so on [14]. The peel and pulp of the banana fruit have also shown to have both antifungal and antibiotic components [14].

This study aims at obtaining banana drying data with particular focus on the effect of temperature on the availability of the composite nutrients, especially carbohydrates, of the banana fruit after drying at different temperatures, for treated and untreated bananas.

\section{METHODOLOGY}

Fully ripe and ready to eat banana of the Musa acuminata descent were bought from Cafeteria 2 in Covenant University, Ota, Ogun State, Nigeria.

\subsection{Sample Preparation}

The bananas were peeled and cut into an average width of $5 \mathrm{~mm}$ using a banana slicer. $100 \mathrm{~g}$ slices were treated using a 1:4 lemon to water juice and allowed to dunk for 10 minutes. It was then allowed to drain in a sieve for another 10 minutes before placing it on the tray dryer. The untreated samples were also cut into $5 \mathrm{~mm}$ sizes and dried on the tray dryer.

\subsection{Drying Procedure}

The tray dryer was preheated to the different working temperatures of $40{ }^{\circ} \mathrm{C}, 50{ }^{\circ} \mathrm{C}, 60^{\circ} \mathrm{C}$ and $70{ }^{\circ} \mathrm{C}$ before $100 \mathrm{~g}$ of sliced banana samples were placed on it. Drying was monitored by taking a sample out of the oven every 30 minutes for weight measurement until no change in weight was observed in the samples.

\subsection{Analysis of Dried Samples}

The standard procedure for proximate analysis [18] was used to determine the composition of all fresh and dried banana samples.

\section{RESULTS AND DISCUSSION}

Results obtained are tabulated in Tables $\mathbf{1}$ and $\mathbf{2}$, while the graphical representation of the results is presented in Figs. (1-6) for both untreated and treated samples, respectively. Increasing the drying temperatures favoured the expulsion of more water from the samples. For example, the air-dried sample (E) had a final moisture content of $21.481 \%$ while it was $13.262 \%$ when dried at $70{ }^{\circ} \mathrm{C}$. Higher temperatures provide more energy for the water molecules to escape from the sample surface as compared to the lower temperatures.

The ash and crude fibre content increased marginally with increased drying temperature. The most sensitive composition to drying temperature was carbohydrate, which increased to almost 4 times the original percentage as the temperature was almost doubled.

Drying is one of the ways to reduce the moisture content, increasing the shelf life of fruits and vegetables generally. The temperature of drying air has a significant effect on the drying time - allowing more moisture to leave rapidly. Most fruits contain significant amounts of natural sugars and as the water is removed from the fruit by drying, the percentage of the nutrients present in the fruit seems to increase. For this reason, 
the carbohydrate content of the dried fruit, for example, is very

high when compared to the fresh fruit. The fat content in most samples was undetected which means that the level in the raw and dried fruit was negligible.

Table 1. Proximate analysis for untreated banana samples.

\begin{tabular}{|c|c|c|c|c|c|c|}
\hline $\begin{array}{c}\text { PARAMETER/ } \\
\text { SAMPLE }\end{array}$ & PROTEIN (\%) & MOISTURE (\%) & ASH (\%) & FAT (\%) & CRUDE FIBRE (\%) & $\begin{array}{c}\text { CARBO- } \\
\text { HYDRATE (\%) }\end{array}$ \\
\hline A1i & 5.02 & 18.5185 & 2.7021 & ND & 1.5873 & 72.1721 \\
\hline A1ii & 5.19 & 17.5676 & 2.8037 & ND & 1.5849 & 72.8538 \\
\hline Mean \pm SD & $5.105 \pm 0.120$ & $18.043 \pm 0.672$ & $2.753 \pm 0.072$ & ND & $1.586 \pm 0.002$ & $72.513 \pm 0.482$ \\
\hline B1i & 10.74 & 14.6341 & 1.6807 & 0.495 & 1.0024 & 71.4452 \\
\hline B1ii & 10.6 & 14.7929 & 1.6304 & 0.4924 & $1.004 \pm 0.002$ & 71.4819 \\
\hline Mean \pm SD & $10.670 \pm 0.099$ & $14.714 \pm 0.112$ & $1.656 \pm 0.036$ & $0.494 \pm 0.002$ & 1.0638 & $71.464 \pm 0.026$ \\
\hline C1i & 6.02 & 13.4228 & 2.0134 & ND & 1.0612 & 77.48 \\
\hline C1ii & 6.23 & 13.4146 & 2.139 & ND & $1.063 \pm 0.002$ & 77.1552 \\
\hline Mean \pm SD & $6.125 \pm 0.148$ & $13.419 \pm 0.006$ & $2.076 \pm 0.089$ & ND & 1.6014 & $77.318 \pm 0.230$ \\
\hline D1i & 3.31 & 13.1579 & 2.0979 & ND & $1.607 \pm 0.008$ & 79.8213 \\
\hline D1ii & 3.54 & 13.3664 & 2.0408 & ND & 1.227 & 79.4514 \\
\hline Mean \pm SD & $3.425 \pm 0.163$ & $13.262 \pm 0.147$ & $2.069 \pm 0.040$ & ND & 1.2238 & $79.636 \pm 0.262$ \\
\hline E1i & 3.84 & 21.9101 & 1.4085 & 0.5805 & $1.225 \pm 0.002$ & 71.0339 \\
\hline E1ii & 4.02 & 21.0526 & 1.8868 & 0.5822 & 1.0923 & 71.2346 \\
\hline Mean \pm SD & $3.930 \pm 0.127$ & $21.481 \pm 0.606$ & $1.648 \pm 0.338$ & $0.581 \pm 0.001$ & 1.0948 & $71.134 \pm 0.142$ \\
\hline F1i & 10.8 & 66.6667 & 0.5348 & 0.334 & $1.094 \pm 0.002$ & 20.5722 \\
\hline F1ii & 10.87 & 66.573 & 0.5181 & 0.3368 & & 20.6073 \\
\hline Mean \pm SD & $10.825 \pm 0.049$ & $66.620 \pm 0.066$ & $0.526 \pm 0.012$ & $0.335 \pm 0.002$ & & $20.590 \pm 0.025$ \\
\hline
\end{tabular}

Legend: $\mathrm{F}=$ Fresh banana samples $\mathrm{E}=$ Air dried banana samples $\mathrm{A}=$ Banana samples dried at $40^{\circ} \mathrm{CB}=$ Banana samples dried at $50{ }^{\circ} \mathrm{CC}=\mathrm{Banana}$ samples dried at 60 ${ }^{\circ} \mathrm{CD}=$ Banana samples dried at $70^{\circ} \mathrm{CND}=$ Not Detected i, ii - duplicate results of analysis $1=$ Untreated banana samples.

Table 2. Proximate analysis for pre-treated banana samples.

\begin{tabular}{|c|c|c|c|c|c|c|}
\hline $\begin{array}{c}\text { PARAMETERS/ } \\
\text { SAMPLE }\end{array}$ & PROTEIN (\%) & MOISTURE (\%) & ASH (\%) & FAT (\%) & CRUDE FIBRE (\%) & $\begin{array}{c}\text { CARBO- } \\
\text { HYDRATE (\%) }\end{array}$ \\
\hline A2i & 4.17 & 17.4359 & 1.7241 & ND & 1.5806 & 75.0894 \\
\hline A2ii & 4.35 & 16.1137 & 1.7857 & ND & 1.5822 & 76.1684 \\
\hline Mean \pm SD & $4.26 \pm 0.127$ & $16.775 \pm 0.935$ & $1.755 \pm 0.044$ & ND & $1.581 \pm 0.001$ & $75.629 \pm 0.763$ \\
\hline B2i & 12.52 & 16.2963 & 1.7391 & 0.494 & 1.0106 & 67.94 \\
\hline B2ii & 12.56 & 15.9509 & 1.7857 & 0.4906 & 1.0136 & 68.1992 \\
\hline Mean \pm SD & $12.540 \pm 0.028$ & $16.124 \pm 0.244$ & $1.762 \pm 0.33$ & ND & $1.012 \pm 0.002$ & $68.070 \pm 0.183$ \\
\hline C2i & 4.54 & 13.6364 & 1.8519 & ND & 1.0582 & 78.9135 \\
\hline C2ii & 4.7 & 13.8889 & 1.8634 & ND & 1.0603 & 78.4874 \\
\hline Mean \pm SD & $4.620 \pm 0.113$ & $13.763 \pm 0.179$ & $1.858 \pm 0.008$ & ND & $1.059 \pm 0.001$ & $78.700 \pm 0.301$ \\
\hline D2i & 6.44 & 14.557 & 2.439 & ND & 1.676 & 7.6779 \\
\hline D2ii & 6.58 & 14.3713 & 2.6087 & ND & $1.677 \pm 0.001$ & 74.888 \\
\hline Mean \pm SD & $6.510 \pm 0.099$ & $14.464 \pm 0.131$ & $2.524 \pm 0.120$ & ND & 1.1976 & $74.825 \pm 0.089$ \\
\hline E2i & 14.74 & 21.6418 & 1.8293 & 0.3029 & 1.1932 & 60.2884 \\
\hline E2ii & 14.86 & 21.3483 & 1.8639 & 0.3023 & $1.195 \pm 0.003$ & 60.4323 \\
\hline Mean \pm SD & $14.800 \pm 0.085$ & $21.495 \pm 0.208$ & $1.847 \pm 0.024$ & $0.303 \pm 0.00$ & 1.0989 & $60.360 \pm 0.102$ \\
\hline F2i & 7.85 & 69.5122 & 0.641 & 0.3296 & 1.0992 & 20.5683 \\
\hline F2ii & 7.79 & 70.3488 & 0.6329 & 0.3247 & $1.099 \pm 0.000$ & $20.186 \pm 0.540$ \\
\hline Mean \pm SD & $7.820 \pm 0.042$ & $69.931 \pm 0.592$ & $0.637 \pm 0.006$ & $0.327 \pm 0.003$ & & \\
\hline
\end{tabular}

Legend: $\mathrm{F}=$ Fresh banana samples $\mathrm{E}=$ Air dried banana samples $\mathrm{A}=$ Banana samples dried at $40{ }^{\circ} \mathrm{CB}=$ Banana samples dried at $50{ }^{\circ} \mathrm{CC}=\mathrm{Banana}$ samples dried at 60 ${ }^{\circ} \mathrm{CD}=$ Banana samples dried at $70{ }^{\circ} \mathrm{CND}=$ Not Detected $\mathrm{i}$, ii - duplicate results of analysis $2=$ Pre-treated banana samples. 


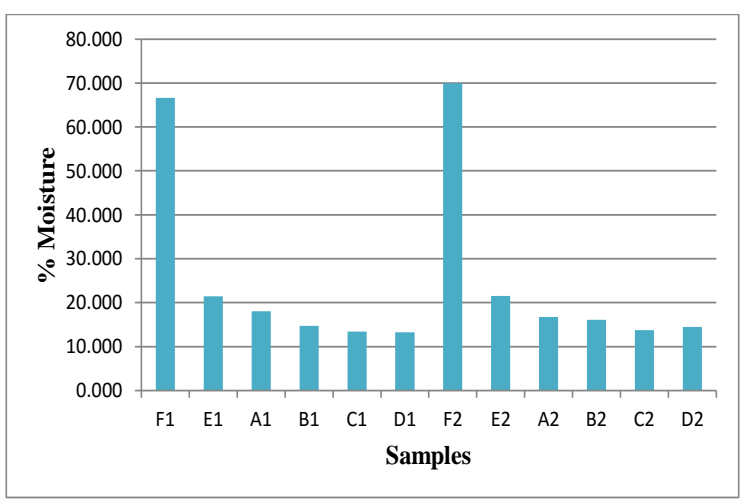

Fig. (1). Moisture present in fresh and dried samples.

Pre-treatment is widely used before drying to improve or retain colour, inactivate enzymes, improve the quality of dried fruit products and sometimes to enhance the drying process. A similar trend of increased carbohydrate content was observed in the pre-treated banana slices as the drying temperature increased, as shown in Table $\mathbf{2}$, but the values are slightly lower than that observed in the untreated slices in Table $\mathbf{1}$. Phytochemical analysis studies have reported that lemon fruit is a rich source of nutrients and bioactive compounds, such as citric acid, ascorbic acid, limonoids, and phenolics, which exhibit multiple biological activities, thus promoting numerous health benefits. Limonoids in lemon juice has also been reported to improve colour and vitamin $\mathrm{C}$ content of dried fruit and is effective in lowering the sugar content of banana fruits $[19,20]$.

More water was present in the treated samples as expected, as shown in Fig. (1). Better moisture removal was observed as temperature increased from samples $\mathrm{F}$ (fresh sample) to D (dried at $70^{\circ} \mathrm{C}$ ).

Results shown in Fig. (2) suggest that the pre-treatment seems to have suppressed the protein in the raw samples of F1 and F2, but upon drying, a higher percentage of protein is preserved in the treated sample than in the untreated one. However, the best protein content was recorded at E2 (air-dried sample) followed by B2 (sample dried at $50^{\circ} \mathrm{C}$ ). No particular trend was observed in all temperatures considered. Results obtained are similar to findings of Correia et al, 2008 [21] but much higher than protein present in Musa paradisiaca (Ekpete et al, 2013) [2]

The ash content of a sample represents the incombustible part of the sample after combustion in a furnace and results obtained from fresh and dried samples are presented in Fig. (3). The fresh banana fruits have less than $1 \%$ ash content as compared to about $12.51 \%$ in tamarind [22]. The ash content in the dried untreated samples shows a progressive increase with temperature but samples dried at $40^{\circ} \mathrm{C}$ (A1) did not follow the trend. No particular trend is followed in the treated samples, but the highest ash content is recorded in the sample dried at $70{ }^{\circ} \mathrm{C}(\mathrm{D} 2)$.

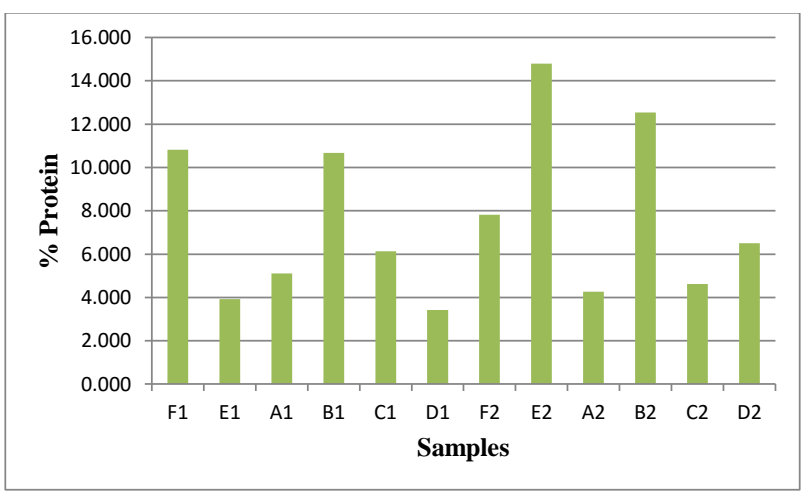

Fig. (2). Protein present in fresh and dried samples.

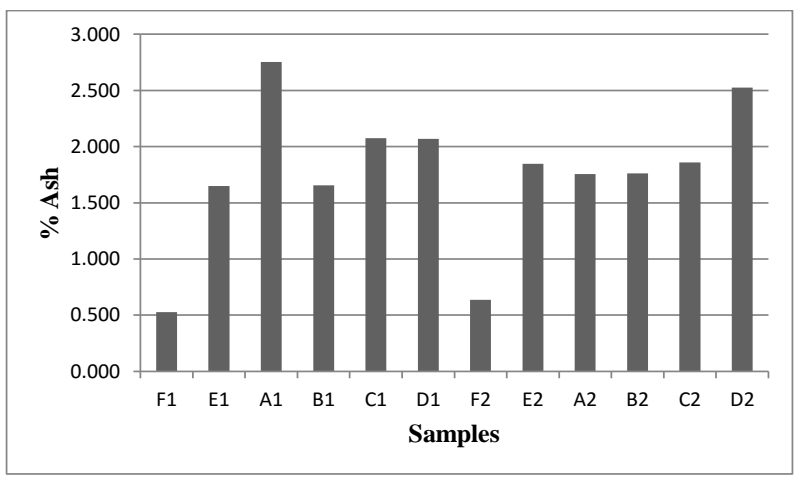

Fig. (3). Ash present in fresh and dried samples.

The fat content of both the treated and untreated fresh samples are the same. Unfortunately, no meaningful inference can be drawn from the Fig. (4), as the fat content in most of the samples could not be detected. This means that the fat content of bananas after drying is very small in amount.

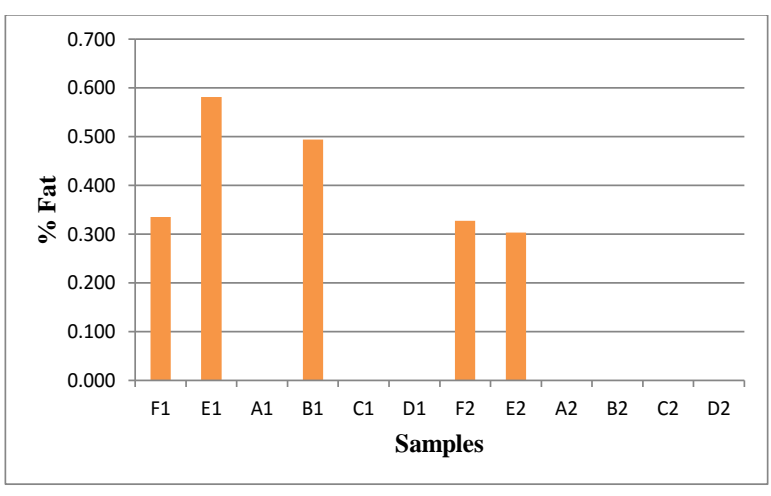

Fig. (4). Fat present in fresh and dried samples.

With the same level of crude fibres in both treated and untreated fresh samples, extreme temperatures considered, A1, A2 (dried at $40^{\circ} \mathrm{C}$ ) and D1, D2 (dried at $70^{\circ} \mathrm{C}$ ) seem to favour the retention of crude fibre in the dried samples as shown in Fig. (5). 


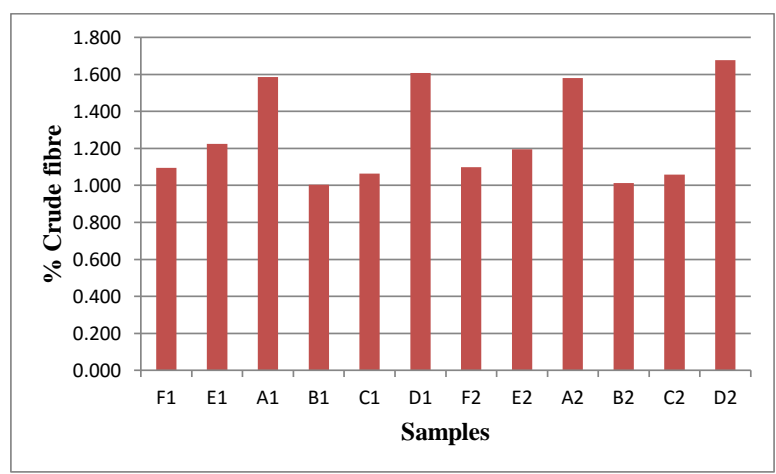

Fig. (5). Crude fibre present in fresh and dried samples.

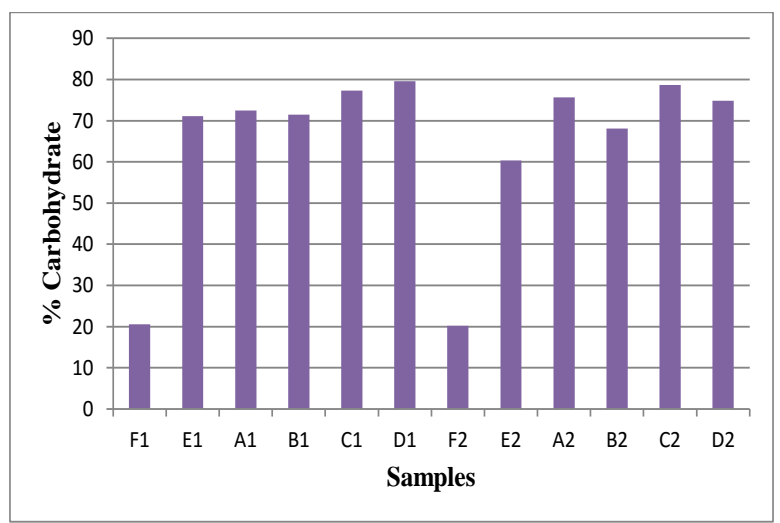

Fig. (6). Carbohydrate content of fresh and dried samples.

The carbohydrate content of the dried fruit is favoured by drying, as shown in Fig. (6). More sugars are present as more water is removed and also, as drying temperature is increased (D1, D2, E1, E2). This is in consonance with results obtained by Correia et al. (2008) [21] in dried chestnuts flours.

It has been shown that tropical storage of some fruits may positively affect the amount of soluble sugars, such as strawberries [23]. Ding et al. [6] recorded a drop in the sugar content of loquat fruit during storage; the sugar content of banana increased with drying as observed in our work. These sugars are present in glucose forms, which make it readily available to the body. Therefore, drying of fruits helps to preserve the carbohydrate and other nutrients in the banana fruit.

\subsection{Colour of Dried Fruit Samples}

By physical observation, during the drying process, the treated samples appeared whiter and brighter than the untreated samples until dried. However, after 1 week, the samples were very close in colour.

\section{CONCLUSION}

Increasing the drying temperature was observed to make more nutrients available in the dried samples. This seems to be good as more energy can be obtained from the dried fruit, which is fit for consumption. The drying of the banana fruit actually made the nutrients more available in dried banana samples, as opposed to the belief that drying destroys the nutrients in fruits.

Dried fruits are recommended to people engaged in weight loss programs. Being low in the glycaemic index makes it attractive to reduce blood sugar levels and also a good enough snack option for Type 2 diabetic patients.

\section{CONSENT FOR PUBLICATION}

Not applicable.

\section{AVAILABILITY OF DATA AND MATERIALS}

The authors confirm that the data supporting the findings of this study are available within the article.

\section{FUNDING}

None.

\section{CONFLICT OF INTEREST}

The authors declare no conflict of interest, financial or otherwise.

\section{ACKNOWLEDGEMENTS}

The Team would like to acknowledge Covenant University, Ota, for the financial support in the publication of this manuscript and Benson Idahosa University, Benin City, for collaborative support.

\section{REFERENCES}

[1] W.P. Silva, C.M. Silva, F.J. Gama, and J.P. Gomes, "Mathematical models to describe thin-layer drying and to determine drying rate of whole bananas", J. Saudi Soc. Agric. Sci., vol. 13, pp. 67-74, 2013. [http://dx.doi.org/10.1016/j.jssas.2013.01.003]

[2] O.A. Ekpete, O.S. Edori, and E.P. Fubara, "Proximate and mineral composition of some nigerian fruits", Br. J. Appl. Sci. Technol., vol. 3, pp. 1447-1454, 2013.

[http://dx.doi.org/10.9734/BJAST/2014/4431]

[3] Z. Pan, "Study of banana dehydration using sequential infared radiation heating and freeze drying", Food Sci. Technol. (Campinas), pp. 1944-1951, 2008.

[4] M.K. Hassan, "Extension of banana shell life", Australas. Plant Pathol., p. 305, 2004.

[http://dx.doi.org/10.1071/AP04011]

[5] S. Toure, "Kibangu-Nkembo.Comparative study of natural solar drying of cassava, banana and mango", Renew. Energy, pp. 975-990, 2004.

[http://dx.doi.org/10.1016/j.renene.2003.09.013]

[6] C. Ding, K. Chachin, and Y. Hamauzu, "Effects of storage temperatures on physiology and quality of loquat fruit", Postharvest Biol. Technol., vol. 14, pp. 309-315, 1998.

[http://dx.doi.org/10.1016/S0925-5214(98)00053-2]

[7] S. Tripathy, "Study on drying and quality characteristics of tray and microwave dried guava", Int. J. Sci. Eng. Res., vol. 7, pp. 965-970, 2016.

[8] O.O. Oluwagbemi, and A.C. Omonhinmin, "Evaluating the relationship between running times and DNAA sequence sizes using a generic-based filtering program", Pac. J. Sci. Technol., vol. 9, no. 2, pp. 656-666, 2013.

[9] "N. Nguyen Do-Trong, J. C. Dusabumuremyi, W. Saeys.CrossPloarized VNIR hypersoectral reflectance imaging for non-destructive quality evaluation of dried banana slices, drying process monitroing and control", J. Food Eng., vol. 238, pp. 85-94, 2018.

[http://dx.doi.org/10.1016/j.jfoodeng.2018.06.013]

[10] Bry-Air, Available at: https://www.bryair.com/news-and-events/articles/tray-drying/https://w ww.bryair.com [Online] 2018.

[11] G.B. Lopez, and F.J.G. Montano, "Functional properties of plantain (Musa sp)", Rev. Med. (Mex.), pp. 22-26, 2014. 
[12] Livestrong. The glycemic index of bananas. Retrieved from www.livestrong.comhttps://www.livestrong.com/article/254976-the-gl ycemic-index-of-bananas/ [Online] Aug 14, 2014.

[13] L. Narayan, "Banana: Awesome fruit crop for society (Review)", Pharma Innova J, pp. 223-228.

[14] K. K. P. Sampath, B. Debjit, S. Duraive, and M. Umadevi, "Traditional and medicinal uses of banana. ", $J$ Pharmacog Phytochem, pp. 51-63, 2012

[15] N. Rajesh, Medicinal benefits of Musa paradisiaca (banana)., Int J Biol Res, 2017, pp. 51-54.

[16] V.E. Efeovbokhan, L. Egwari, E.E. Alagbe, J.T. Adeyemi, and O.S. Taiwo, Production of bioethanol from hybrid cassave pulp and peel using microbial and acid hydrolysis.BioResources , 2, vol. 14. 2019, pp. 2596-2609.

[17] M.J. Roberts, Edible and Medicinal Flowers., New African Books Ltd: Claremont, 1999.

[18] AOAC International.Official Methods of Analysis., $17^{\text {th }}$ ed Gaithersburg, Maryland, USA, 2000.

[19] A. Kelble, "Spices and Type 2 Diabetes", Nutr. Food Sci., 2005. [http://dx.doi.org/10.1108/00346650510585868

20] R. Aller, D.A de Luis, O. Izaola, F. La Calle, L del Olmo, L. Fernandez, T. Arranz, and J.M. Hernandez, "Effect of soluble fiber intake in lipid and glucose levels in healthy subjects: A randomized clinical trial", Diabetes Res. Clin. Pract., vol. 65, no. 1, pp. 7-11, 2004.

[http://dx.doi.org/10.1016/j.diabres.2003.11.005] [PMID: 15163472]

[21] P. Correia, A. Antonio, and M.L. Beirao-da-Costa, "The effect of drying temperatures on morphological and chemical properties of dried chestnuts flour", J. Food Eng., vol. 90, pp. 325-332, 2009. [http://dx.doi.org/10.1016/j.jfoodeng.2008.06.040]

[22] M.K.C. Untalan, I.F.R. Perez, G.H. Yeyes, K.M.H. Escalona, L.D. De Guzman, and R.F.L. Lumanglas, "Proximate analysis and antioxidant properties of selected fruits in Batangas", Asia Pacific J Multidiscip Res, vol. 3, no. 4, pp. 41-45, 2015.

[23] B.R. Cordenunsi, M.I. Genovese, J.R. Oliveira, M.A. Neuza, H.R. Jose, and S.F. Lajolo, "Effects of temperature on the chemical composition and antioxidant activity of three strawberry cultivars", Food Chem., vol. 91, pp. 113-121, 2005.

[http://dx.doi.org/10.1016/j.foodchem.2004.05.054]

C) 2020 Alagbe et al.

This is an open access article distributed under the terms of the Creative Commons Attribution 4.0 International Public License (CC-BY 4.0), a copy of which is available at: https://creativecommons.org/licenses/by/4.0/legalcode. This license permits unrestricted use, distribution, and reproduction in any medium, provided the original author and source are credited. 